


\section{DISCLAIMER}

This report was prepared as an account of work sponsored by an agency of the United States Government. Neither the United States Government nor any agency Thereof, nor any of their employees, makes any warranty, express or implied, or assumes any legal liability or responsibility for the accuracy, completeness, or usefulness of any information, apparatus, product, or process disclosed, or represents that its use would not infringe privately owned rights. Reference herein to any specific commercial product, process, or service by trade name, trademark, manufacturer, or otherwise does not necessarily constitute or imply its endorsement, recommendation, or favoring by the United States Government or any agency thereof. The views and opinions of authors expressed herein do not necessarily state or reflect those of the United States Government or any agency thereof. 


\section{DISCLAIMER}

Portions of this document may be illegible in electronic image products. Images are produced from the best available original document. 


\section{LEGAL NOTICE}

This report was prepared as an account of Guvernment sponsored work. Neither the United States, nor the Commission, nor any person acting on behalf of the Commission:

A. Makes any warranty or representation, expressed or implied, with respect to the accuracy, completeness, or usefulness of the information contained in this report, or that the use of any information, apparatus, method, or process disclosed in this report may not infringe privately owned rights; or

B. Assumes any liabilities with respect to the use of, or for damages resulting from the use of any information, apparatus, method, or process disclosed in this report.

As used in the above, "person acting on behalf of the Commission" includes any employee or contractor of the Commission, or employee of such contractor, to the extent that such employee or contractor of the Commission, or employee of such contractor prepares, disseminates, or provides access to, any information pursuant to his employment or contract with the Commission, or his employment with such contractor.

Printed in the United States of America.

Available from

Clearinghouse for Federal Scientific and Technical Information

National Burcau of Standards, U. S. Department uf Cummerce

Springfield, Virginia 22151

Price: Printed Copy $\$ 3.00$; Microfiche $\$ 0.65$ 
CRITICAL MASSES OF OIL REFLECTED, ENRICHED URANIUM METAL ASSEMBLIES

WITH POLYURETHANE CENTERS

B. B. Ernst

THE DOW CHEMICAL COMPANY ROCKY FLATS DIVISION

P. O. BOX 888

GOLDEN, COLORADO 80401

U. 5. ATOMIC ENERGY COMMISSION CONTRACT AT(29-1)-1106 
RFP-1017 


\section{CONTENTS}

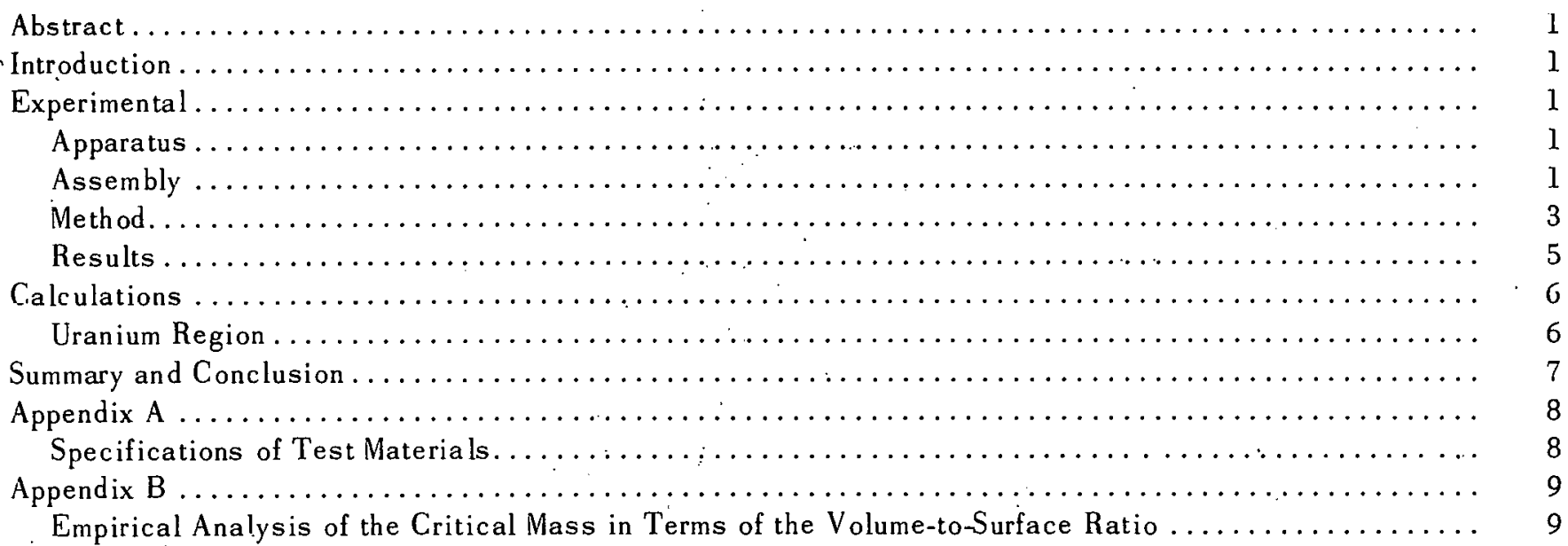




\section{A C K N OW L E D G M N T S}

'l'he author wishes to acknowledge the assistance of $\mathrm{D}$. C. Cioonfield, L. A. FitzRandolph, and H. E. Clark in performing the machine calculations and to H. W. King for fabricating the polyurethane centers. 'I'he experimental work was done by: H. E. Clark, B. B. Ernst, D. R. Ferguson, L. A. FitzRandolph, D. C. Hunt, G. G. Risley, R. E. Rothe, and G. Tuck. 


\title{
Critical Masses of Oil Reflected, Enriched Uranium Metal Assemblies with Polyurethane Centers
}

\author{
B. B. Ernst
}

\begin{abstract}
The critical masses of oil reflected, enriched uranium spherical assemblies of inside uranium radii, $0.0-, 4.017-, 8.010-$, and $12.011-\mathrm{cm}$ with a low-density foam in the central cavity were measured to be 24.3-, 31.65-, 52.1-; and 81.3kilograms. Critical masses were determined by recipruial multiplication measurements on fully reflected assemblies and are compared with calculations.
\end{abstract}

\section{INTRODUCTION}

The critical masses of enriched uranium spherical assemblies filled with a low-density polyurethane and reflected with Texaco 522 oil were me asured by using neutron multiplication measurements. The critical mass of the polyurethane filled, oil reflected assembly is then compared with the critical mass of an oil filled, oil reflected spherical assembly having the same inner radius.

A comparison of one-Dimensional Transport FORTRAN (DTF) calculations ${ }^{1}$ with experiment are reported.

The fit of the experimental data to an empirical equation of the form $M_{c}=C /(V / S)-B+A$ as previously reported in RFP-939 $9^{2}$ is shown in Appendix $B$.

\section{EXPERIMENTALL}

Apparatus: The apparatus used consisted of a reflector tank, oil reservoir, associated pumps, valves, plumbing, . and neutron detection equipment, which has previously been reported by $G$. Tuck. ${ }^{3}$ The apparatus is shown

\footnotetext{
${ }^{1}$ B. G. Carlson, W. J. Worlton, W. Guber, and M. Shaping, DTF Users Manual, UNS Phy/Math-3321, Volume I (1963) and Volume II (1964). United Nuclear Corporation.

${ }^{2}$ Bruce B. Ernst, C. L. Schuske, and Howard W. King. "Empirical Analysis of Spheriral and Hemispherical Asscmblics of EnrichedUranium Metal." RFP-939. Rocky Flats Division, The Dow Chemical Company, Golden, Colorado.

${ }^{3}$ For further details of the test equipment, see Grover Tuck. “Enriched Uranium-Metal Measurementș, No, I." RFP-9n7. Rocky Flats Division, The Dow Chemical Company, Golden, Colorado.
}

in Figure 1. The mounting-table was removed for the 12.0-cm run and the detectors were placed under the tank as shown in Figure 3. An aluminum mount, shown in Figure 2, was used to hold the assemblies. Other than this mount, no other material except the reflector oil was within $19-\mathrm{cm}$ of the assembly.

Source and counter locations are shown in Figure 3. The source was $\mathrm{Po-Be}$ having a $\mathrm{Q}$ value of approximately $2 \times 10^{6} \eta / \mathrm{sec}$. The $\mathrm{BF}_{3}$ neutron detectors were Reuter-Stokes, Model RSN-44A.

The oil height was determined by viewing a sightgage through closed circuit television.

Assembly: The experimental assembly shown in Figure 4 was built from experimental components which were concentric shells of enriched uranium as shown in Figure 5 and filled with low-density polyurethane. Each individual component had a density of 18.675 $\pm 0.065-\mathrm{g} / \mathrm{cm}^{3}$ and was enriched to $93.1 \%{ }^{235} \mathrm{U}$. Each $1 / 3-\mathrm{cm}$ thick experimental component had a mountinghole at the pole $0.714-\mathrm{cm}$ in diameter and four equispaced $0.3175-\mathrm{cm}$ diameter holes near the equatorial plane which were used for lifting the individual components during disassembly of an experimental assembly.

The experimental assembly was placed onto the aluminum mounting-stand and.was held in place with a mild-steel mounting-bolt which went through the poleholc and screwed into the stand.

The machining tolerance gaps, averaging $0.010-\mathrm{cm}$ between the experimental components, were filled with petroleum jelly during a test to prevent the sudden influx of oil into these gaps during reflector addition thereby increasing the reactivity. The petroleum jelly was used because its nuclear properties are similar to the reflector oil.

Polyurethane Duo-foam (Plasticrafts, Inc., Denver, Colorado) which is a low-density foam, was molded into the shape of the central cavity and was then placed inside the test assemblies during an experiment to prevent oil from accidentally entering the central region and increasing the reactivity during the addition of reflector oil. 


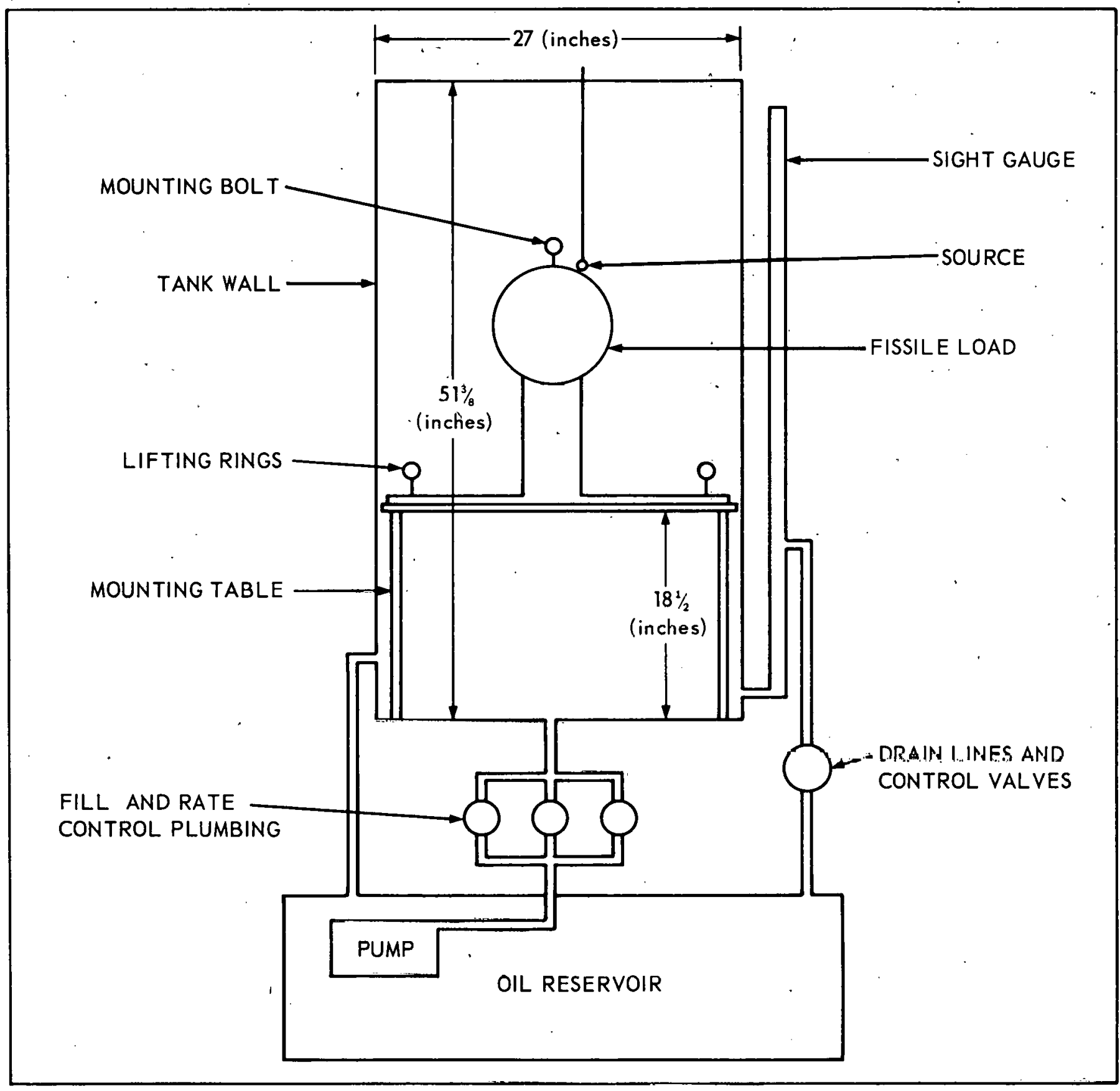

FIGURE 1. Experimental Apparatus. 

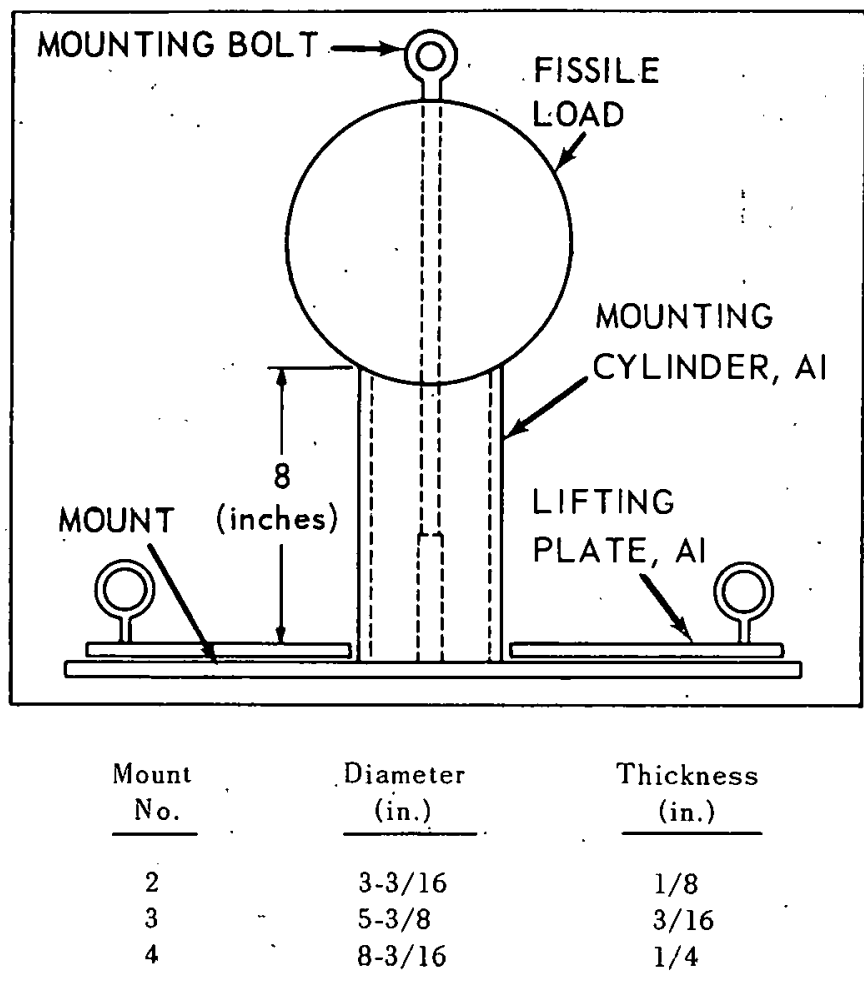

FIGURE 2. Mount and Fissile Assembly.

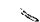

- FIGURE 3. Source-Detector Geometry.

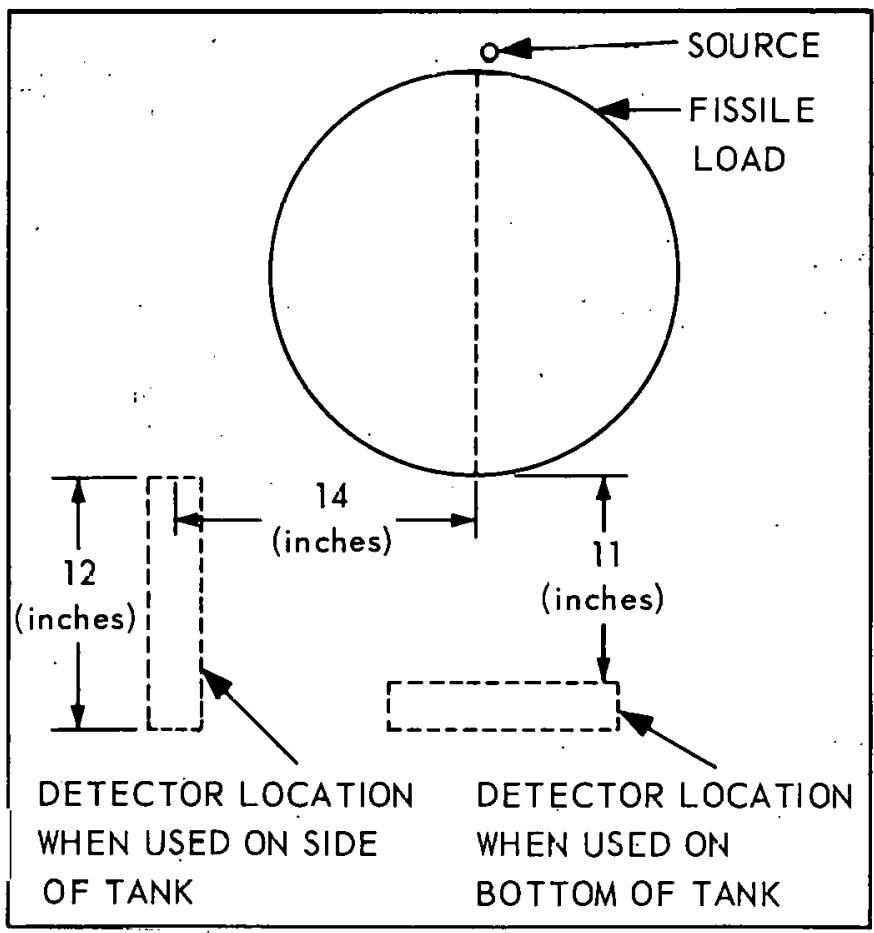

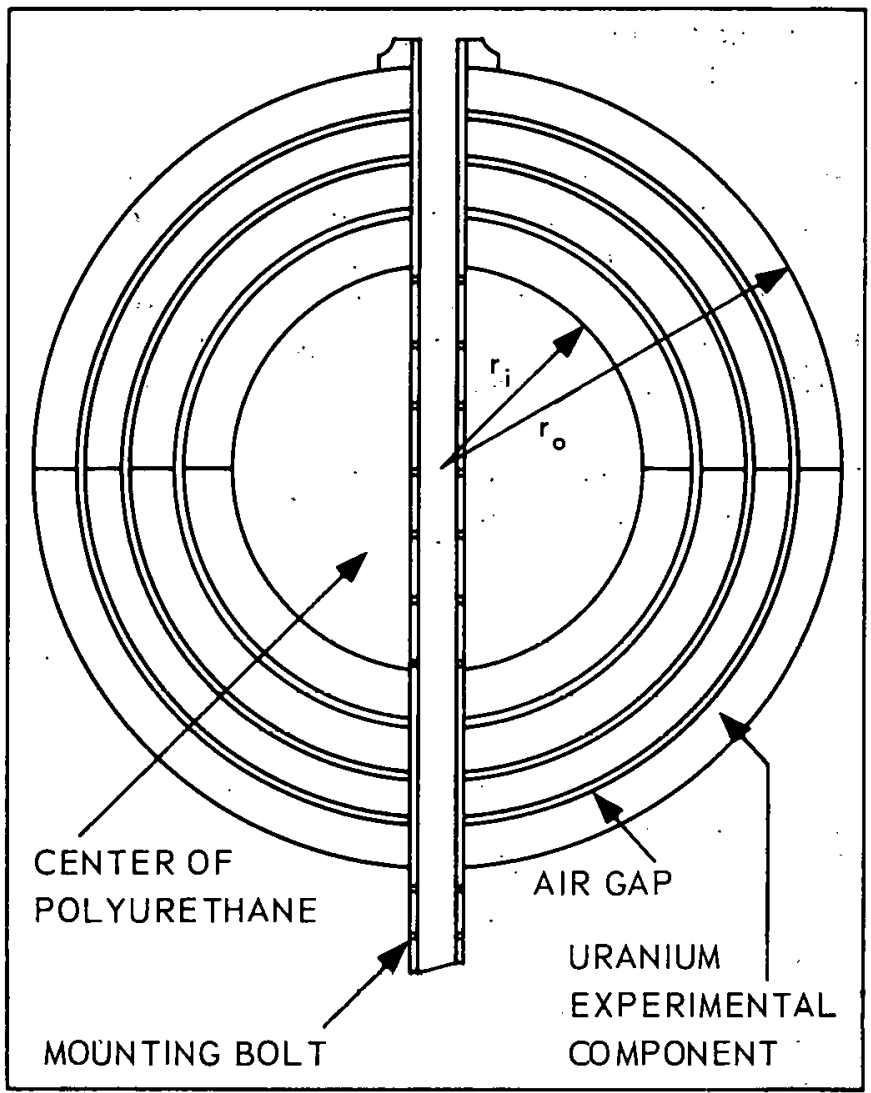

FIGURE 4. Typical Experimental Assembly.

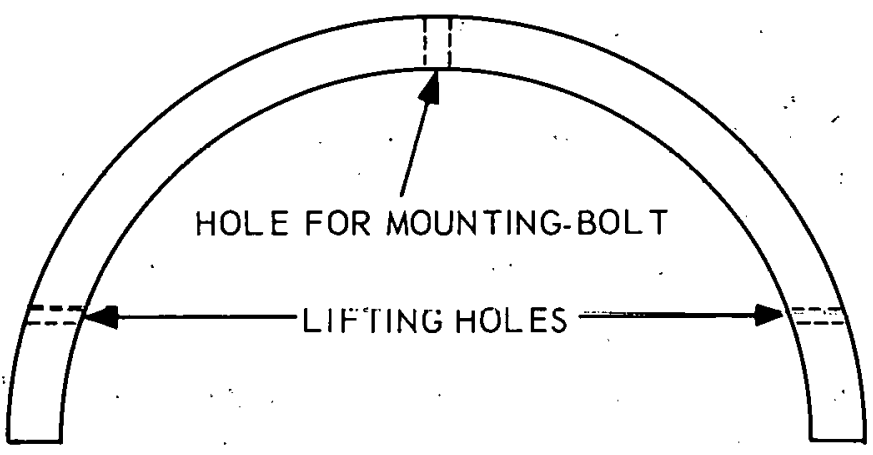

FIGURE 5. Enriched Uranium Experimental Component.

For specifications of the test materials, see Appendix A.

Method: Inverse multiplication measurements were made on enriched uranium assemblies filled with a low-density polyurethane foam and reflected with Texaco 522 oil. These measurements were used to 
determine the critical mass of assemblies having different inside radii.

To determine an inverse multiplication, which we are defining to be $\mathrm{C}_{\mathrm{o}} / \mathrm{C}$, it was necessary to determine a $C_{0}$. Two methods were used to do this. The first was to use a steel mockup of the test assembly with the outside radius as nearly equal to the calculated critical radius as could be obtained with the existing experimental components. The second method of obtaining $C_{o}$ was to use an enriched uranium load that was approximately one-half of the calculated critical mass.

Fur buth methods the $C_{0}$ was determined as a function of oil height.

The steel mockup method for obtaining $\mathrm{C}_{0}$ was used on the $4.0-\mathrm{cm}$ and $8.0-\mathrm{cm}$ inner radii assemblies whereas the one-half critical mass me thod for obtaining $C_{0}$ was used on all assemblies.

Using two different $\mathrm{C}_{\mathrm{o}}$ 's would extrapolate to the same critical mass, but, by using one-half the critical mass as $\mathrm{C}_{0}$ the reciprocal multiplication curve has a slope, which provides a better critical mass extrapolation than the curve that uses the steel mockup as background $\left(C_{o}\right)$. This is shown in Figures 6 and 7 where both methods were used to extrapolate the critical mass.

After $\mathrm{C}_{0}$ was determined, an experimental assembly was constructed consisting of a low-density polyurethane sphere in the central cavity followed by a series of experimental concentric, spherical, uranium componeits.

This assembly was then mounted on an aluminum mounting stand with a solid, mild-steel mountingbolt which went through the pole-holes of the assembly and screwed into the mounting-rod of the stand. (See Figuro 2.)

The assembly and mount were then placed in the test tank and the source was lowered until it touched the test assembly near the top. The count rate at various oil heights $(C)$ was measured and a curve of $C_{0} / C$ versus oil height for this assembly was platted until the oil was at least $19-\mathrm{cm}$ over the top of the assembly. The $\mathrm{C}_{\mathrm{o}} / \mathrm{C}$ for the oil height corresponding to full reflection was then plotted as a function of the mass of the test assembly. This assembly was then

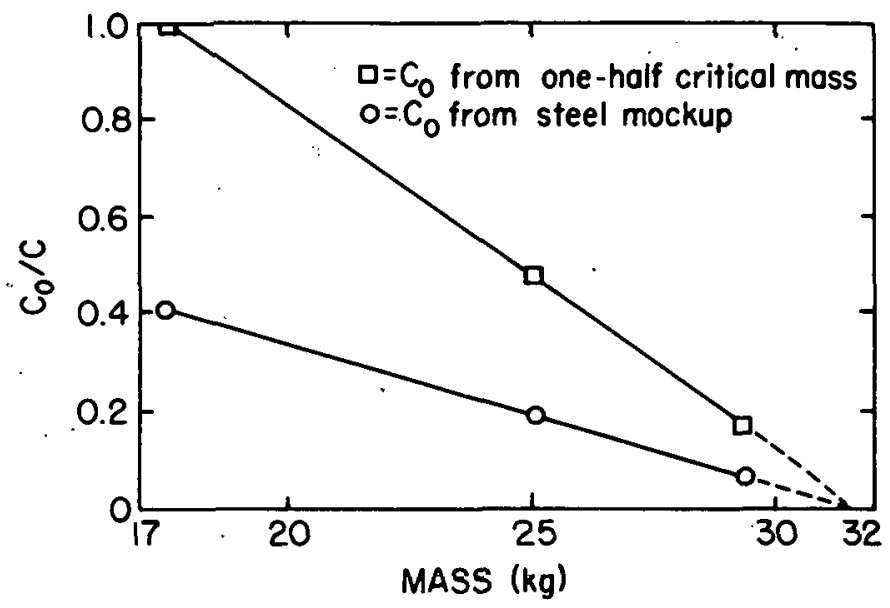

FICURE 6. Critical Mass : Extrapolation 4.0-cm Inner Radius Spherical Assembly.

FIGUKE' 7. 'Critical Mass Extrapolation 8.0-cm Inner Radius Sphericol Assembly.

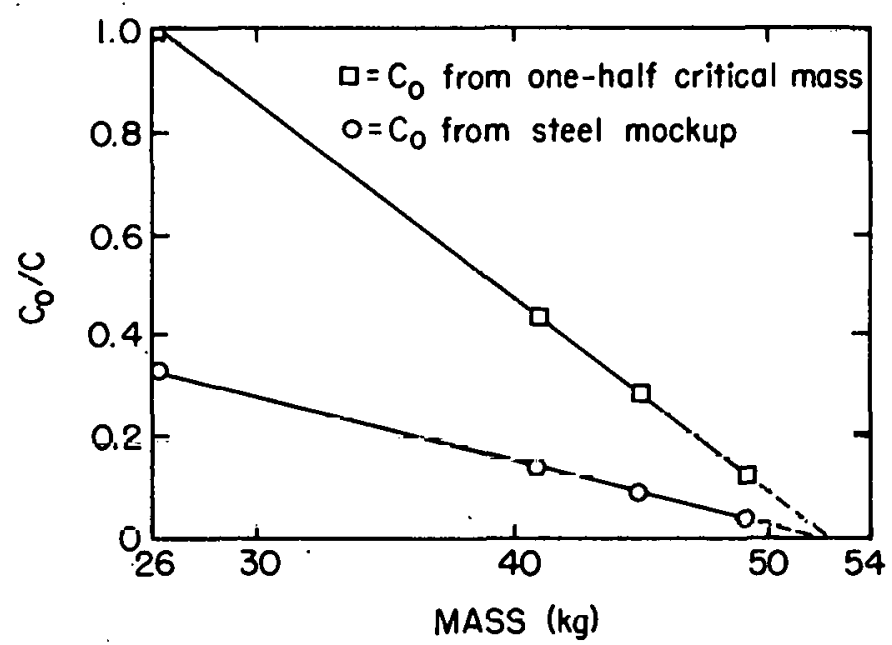

removed from the tank and another component was added to the outside of the assembly increasing the mass of the assembly but keeping the inner radius constant. Normally, two experimental rnmponents would be added at a time in order to preserve the symmetry of an assembly; but, if the addition. of two of these components would incrcase the mass by too large an increment, only one component would be added making an asymmetric assembly. (See Figure. 8.) This new assembly was then placcd in the tank and the procedure was repeated. This was done until the plot of $\mathrm{C}_{0} / \mathrm{C}$ versus mass showed that the addition of one more component would be more than critical if fully reflected. The extrapolated critical mass was then obtained from this . plot of $\mathrm{C}_{0} / \mathrm{C}$ versus mass. 
Results: Solid Sphere: Inside Radius $=0.00-\mathrm{cm}$.

The measurements made on the solid sphere have previously been reported by $\mathrm{G}$. Tuck ${ }^{3}$ as $24.2 \pm 0.3$ :kilograms.

Spherical Assembly: Inside Radius = 4.017-cm.

Assemblies weighing 17.616-, 25.072-, and 29.336-kg, were fully reflected and the ir $\mathrm{C}_{0} / \mathrm{C}$ values were measured. The $31.685-\mathrm{kg}$ assembly had an indicated multiplication of 116 at $9.0-\mathrm{cm}$ of oil over the top of the assembly. Figure 6 shows the critical mass extrapolation. The two curves represent the two different methods used for $\mathrm{C}_{0}$. The $\mathrm{a}$ symbol represents the method of obtaining $\mathrm{C}_{\mathrm{o}}$ from one-hall the critical mass, while the 0 symbol represents the method of obtaining $\mathrm{C}_{0}$ from the steel mockup. Using one-half the critical mass as $\mathrm{C}_{0}$ extrapolates to $31.6-\mathrm{kg}$, whereas using the steel mockup as $\mathrm{C}_{0}$ extrapolates to 31.7 -kilograms. From the se two

${ }^{3}$ Loc. cit. Page 1. curves, the extrapolated critical mass is taken to be $31.65+0.7-0.9$ kilograms.

TABLE I. Enriched Uranium Spherical Assembly.

\begin{tabular}{|c|c|c|c|}
\hline \multirow[b]{2}{*}{ Mass (kg) } & \multicolumn{2}{|c|}{$\mathrm{IR}=4.017-\mathrm{cm}$} & \multirow[b]{2}{*}{$\begin{array}{r}\text { Avg. Uranium } \\
\text { Density }\left(\mathrm{g} / \mathrm{cm}^{3}\right. \\
\end{array}$} \\
\hline & $\left(C_{0}\right) / C^{a}$ & $\begin{array}{c}\text { Assembly O.R. } \\
(\mathrm{cm})\end{array}$ & \\
\hline 17.616 & 0.409 & 6.670 & 18.13 \\
\hline 25.072 & 0.196 & 7.332 & 18.17 \\
\hline 29.336 & 0.072 & 7.667 & 18.15 \\
\hline $31685^{b}$ & $0.009^{c}$ & $\left\{\begin{array}{l}7.667 \\
8.003\end{array}\right\}$ & 18.15 \\
\hline
\end{tabular}

${ }^{c}$ Measured at $9.0-\mathrm{cm}$ of oil over the top of the assembly.

Spherical Assembly: Inside Radius 8.010-cm.

Measurements were made on assemblies weighing 26.208-, 40.884-, 44.802-, and 49.009-kilograms.

Figure 7 shows the critical mass extrapolation. Again, the two curves represent the two methods used for $C_{0}$. The $\square$ symbol representing $C_{o}$ as

FIGURE 8. Asymmetric Assembly.

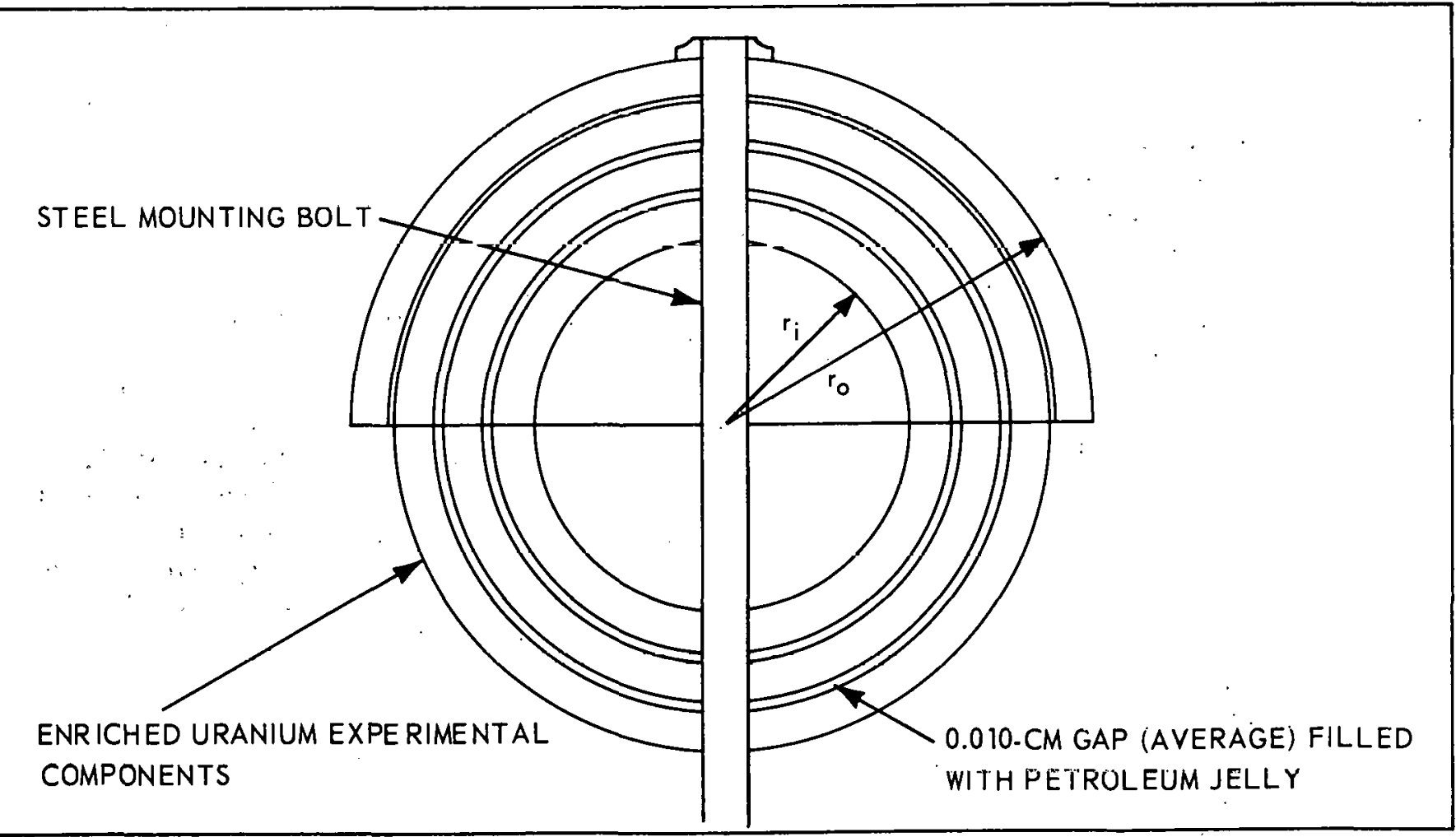


one-half the critical mass indicates that $52.3-\mathrm{kg}$ is the critical mass, while the $O$ symbol representing $\mathrm{C}_{\mathrm{o}}$ as the steel mockup shows that $52.0-\mathrm{kg}$ would be the criticai mass.

The 49.009-kg assembly was an asymmetric assembly as shown in Figure 8. For this reason, a second run was made to measure $\mathrm{C}_{0} / \mathrm{C}$ with the load inverted. The $\mathrm{C}_{o} / \mathrm{C}$ with the heavy top was 0.041 and the $\mathrm{C}_{\mathrm{o}} / \mathrm{C}$ with the light top was 0.042 . The average $\mathrm{C}_{\mathrm{o}} / \mathrm{C}$ was used to determine the critical mass. The extrapolated critical mass is $52.1+1.2-1.0$-kilograms.

TABLE II. Enriched Uranium Spherical Assemblies.

\begin{tabular}{|c|c|c|c|}
\hline \multirow[b]{2}{*}{ Mass ( kg) } & \multicolumn{2}{|c|}{$\mathrm{IR}=8.010-\mathrm{cm}$} & \multirow[b]{2}{*}{$\begin{array}{l}\text { Avg. Uranium } \\
\text { Density }\left(\mathrm{g} / \mathrm{rm}^{3}\right)\end{array}$} \\
\hline & $\left(C_{0}\right) / C^{0}$ & $\begin{array}{c}\text { Assembly O.R. } \\
\text { (Lru) }\end{array}$ & \\
\hline \multirow[t]{3}{*}{$26.208^{b}$} & 0.326 & As ymunetrir. & 18.18 \\
\hline & & 9.667 & \\
\hline & : & 9.333 & \\
\hline & & Asymmetric & \\
\hline \multirow[t]{2}{*}{$40.884^{b}$} & 0.144 & 10.000 & 18.15 \\
\hline & & 10.334 & \\
\hline \multirow[t]{2}{*}{44.802} & 0.0928 & 10.334 & 18.14 \\
\hline & . & Asymmetric & \\
\hline \multirow[t]{2}{*}{$49.009^{b}$} & 0.041 & 10.334 & 18.14 \\
\hline & 0.042 & 10.670 & \\
\hline
\end{tabular}

Spherical Assemblies: Inside Radius = 12.011-cm.

The experimental run data is shown in Figure 9. Medsurements were made on assemblies weighing 35.301-, 62.453-, 76.959-, and 84.578-kilograms. The $84.578-\mathrm{kg}$ assembly had an indicated multiplication of 91 at 1.5 -cill uver the top of the assembly. The extrapolated critical mass is $81.3 \pm 3.0$-kilograms.

TABLE III. Enriched Uranium Spherical Assemblies.

$$
\text { IR }=12 n 11 \text { irm }
$$

\begin{tabular}{|c|c|c|c|}
\hline Mass $\left(\mathrm{kg}_{\mathrm{g}}\right)$ & $\left(C_{0}\right) / C^{a}$ & $\begin{array}{c}\text { Assembly O.R. } \\
(\mathrm{cm}) \\
\end{array}$ & $\begin{array}{r}\text { Avg. Wranium } \\
\text { Density }\left(\mathrm{g} / \mathrm{cm}^{3}\right) \\
\end{array}$ \\
\hline 35.301 & 1.000 & 13.001 & 18.13 \\
\hline 62.453 & 0.432 & I 3.670 & 18.14 \\
\hline 76.959 & 0.103 & 14.001 & 18.15 \\
\hline $84.578^{b}$ & $0.011^{c}$ & & 18.16 \\
\hline
\end{tabular}

${ }^{a} C_{0}$ was taken as the $35.301-\mathrm{kg}$ assembly.

bAsymmetric Assembly.

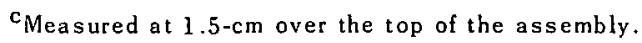

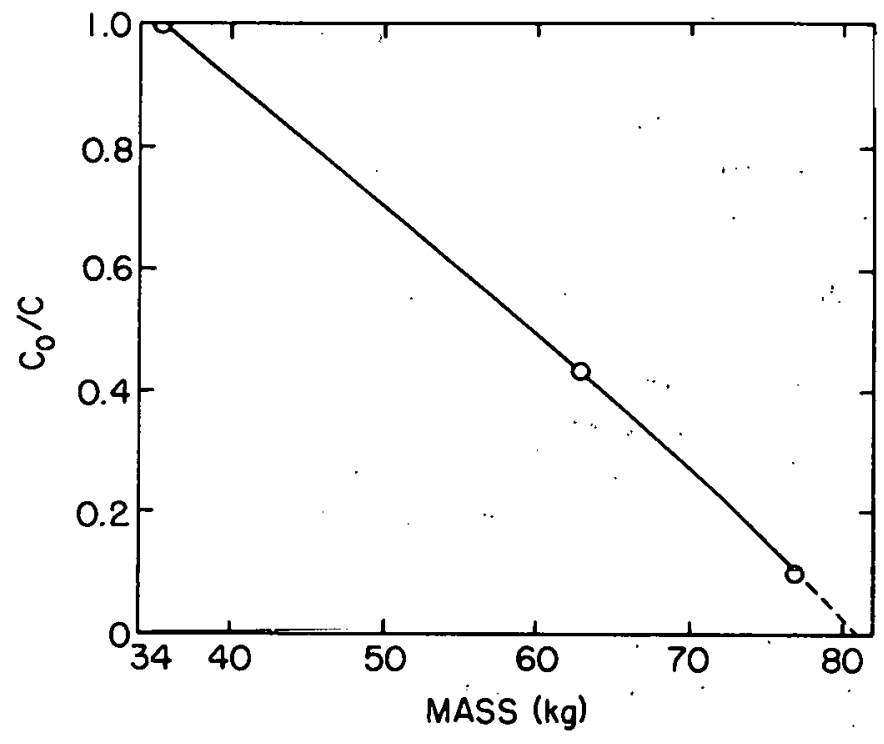

FICURE 9. Ciritical Mass Extrapolation 12.0-cm Inner Radius Spherical Assembly.

\section{CALCULATIONS}

DTF calculations were made for enriched uranium assemblies, reflected with oil and having either a void center or a polyurelliane center. These calculations used the D'lF' ${ }^{1}$ code with the $\mathrm{S}_{4}$ approximation and Hansen and Roach ${ }^{4}$ sixteen-group crnsssections. The petroleum jelly in the gaps was assumed to be oil homogenized with the uranium in the assembly. The input parameters were:

Polyurethane Region:

The number densities used were:

$$
\begin{aligned}
& N_{C}=0.0014763 \times 10^{24} \text { atoms } / \mathrm{cm}^{3} \\
& N_{H}=0.0020080 \times 10^{24} \text { atoms } / \mathrm{cm}^{3} \\
& N_{N}=0.0001296 \times 10^{94} \text { atoms } / \mathrm{cm}^{3}
\end{aligned}
$$

Uranium Region: The average uranium density of the assemblies used in the experiments was calculated to be $18.15-\mathrm{g} / \mathrm{cm}^{3}$. To obtain the reduced oil density that was used in the uranium region the following technique was used. The actual physical volume of - a solid critical sphere was calculated from the mea: sured value of the outer radius of the test assembly.

\footnotetext{
${ }^{1}$ Loc. cit. Page 1.

${ }^{4}$ G. E. Hansen and W. H. Roach. "Six and Sixtecn Croup Cross Sections for Fast and Intermediate C'ritical Assemblies." LAMS2543. University of California, Los Alamos Scientific Laboratory. December, 1960.
} 
A volume was then calculated that was necessary to give the weighed mass of the solid sphere if the uranium was at a density of $18.675-\mathrm{g} / \mathrm{cm}^{3}$. The difference between these two volumes is the volume of the machining gaps that could be filled with oil. The mass of this volume of oil was then assumed to be homogenized throughout the solid sphere giving a reduced oil density of $0.236558-\mathrm{g} / \mathrm{cm}^{3}$. This reduced oil density was then used to calculate the number densities for this region.

The number densities used for this uranium region were:

$$
\begin{aligned}
{ }^{235} \mathrm{~N} & =0.0432955 \times 10^{24} \text { atoms } / \mathrm{cm}^{3} \\
{ }^{238} \mathrm{~N} & =0.0031585 \times 10^{24} \text { atoms } / \mathrm{cm}^{3} \\
\mathrm{~N}_{\mathrm{H}} & =0.0023701 \times 10^{24} \text { atoms } / \mathrm{cm}^{3} \\
\mathrm{~N}_{\mathrm{C}} & =0.0012798 \times 10^{24} \text { atoms } / \mathrm{cm}^{3}
\end{aligned}
$$

Oil Reflector Regions were:

$$
\begin{aligned}
& \mathrm{N}_{\mathrm{H}}=0.069712 \times 10^{24} \text { atoms } / \mathrm{cm}^{3} \\
& \mathrm{~N}_{\mathrm{C}}=0.037644 \times 10^{24} \text { atoms } / \mathrm{cm}^{3}
\end{aligned}
$$

TABLE IV. DTF Calculated Critical Masses of Oil Heflected Polyurethane Filled Spherical Assemblies.

\begin{tabular}{ccc}
$\begin{array}{c}\text { Uranium } \\
\text { Inner Radius } \\
(\mathrm{cm})\end{array}$ & $\begin{array}{c}\text { Enriçhed Uranium } \\
\text { Thickness } \\
(\mathrm{cm})\end{array}$ & $\begin{array}{c}\text { Mass } \\
(\mathrm{kg})\end{array}$ \\
\hline 0.000 & 6.668 & 22.539 \\
4.017 & 3.697 & 29.959 \\
8.010 & 2.546 & 50.353 \\
12.011 & 2.019 & 78.207
\end{tabular}

TABLE V. DTF . Calculated Critical Masses of Oil Neflected Void Center Sphcrical Asscmblies.

\begin{tabular}{ccc}
$\begin{array}{c}\text { Uranium } \\
\begin{array}{c}\text { Inner Kadius } \\
(\mathrm{cm})\end{array}\end{array}$ & $\begin{array}{c}\text { Enriched Uranium } \\
\text { Ihickness } \\
(\mathrm{em})\end{array}$ & $\begin{array}{c}\text { Mass } \\
\mathbf{( k g )}\end{array}$ \\
\cline { 2 - 3 } 0.000 & 6.668 & 22.539 \\
4.017 & 3.710 & 30.139 \\
8.010 & 2.582 & 51.287 \\
12.011 & 2.076 & 80.297
\end{tabular}

\section{SUMMARY AND CONCLIISION}

The summary of experimental and calculational results is given helow. Figure 1.0 shows the critical mass versus the inside radius. The two solid upper curves are DTF calculated curves while the $O$ symbols are the exporimental points of assemblies filled with polyurethane and reflected with Texaco 522 nil. The curve $\Delta$ is a curve through the experimental points reported

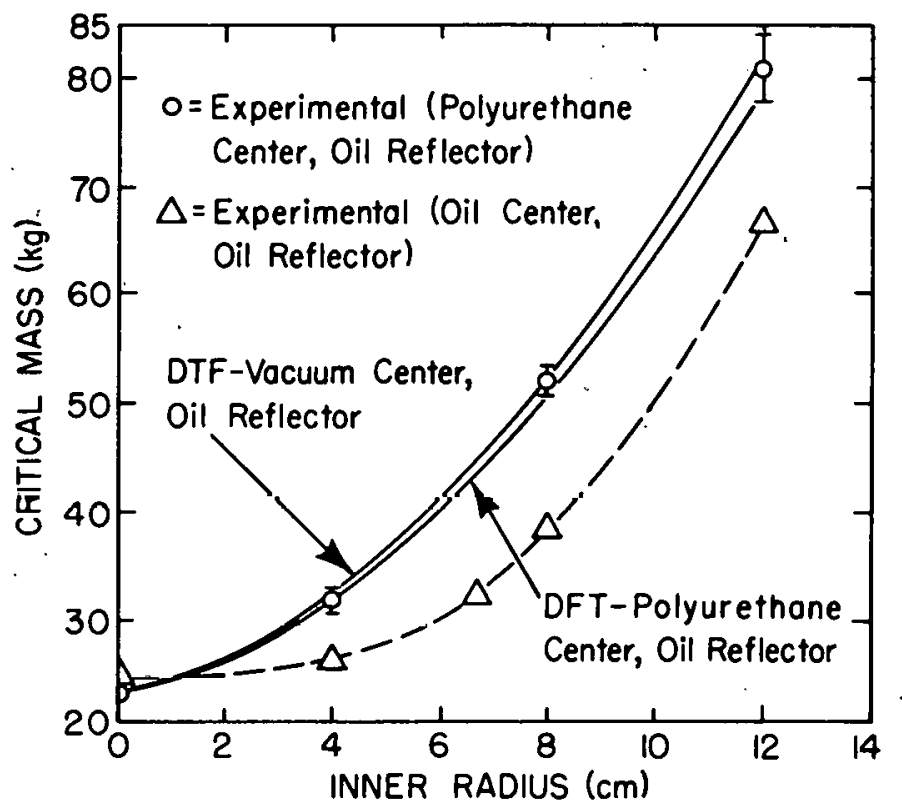

FIGURE 10. Critical Mass Versus Inner Radius.

FIGURE 1l. Critical Enriched Uranium Thickness Versus Inner Radius.

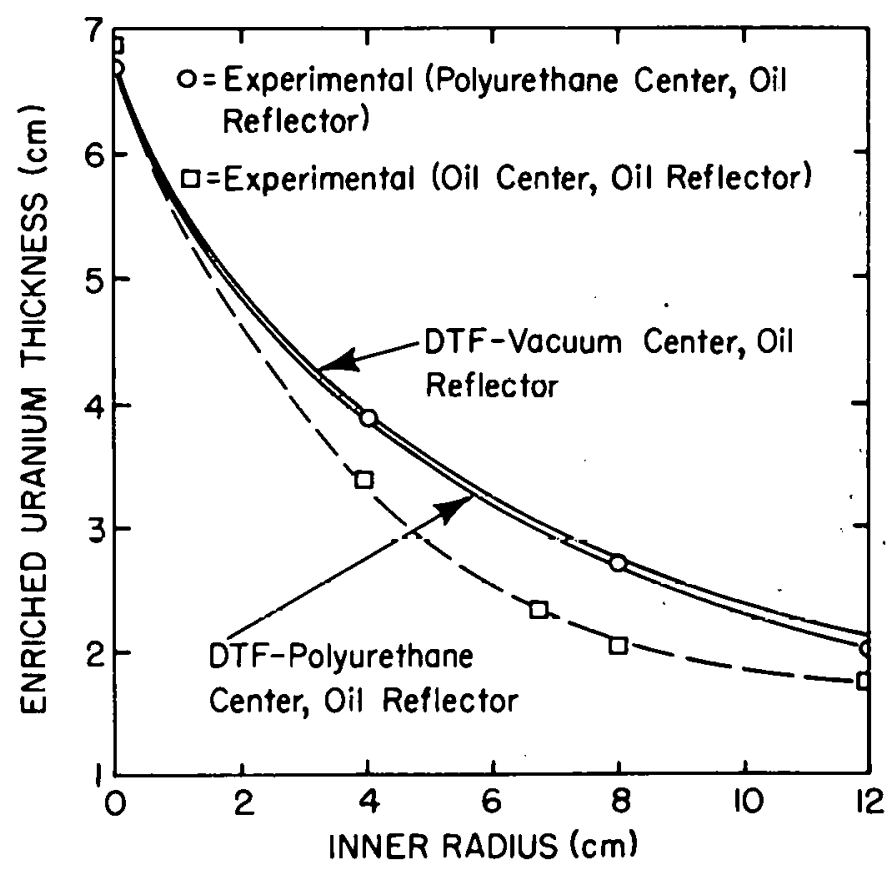

by $\mathrm{G}$. Tuck ${ }^{3}$ for oil filled, and oil reflected spherical assemblies.

Figure 11 shows the critical enriched uranium thickness versus the inner radius. The symbols here have the same meaninge as those in Figurc 10.

\footnotetext{
${ }^{3}$ Loc. cit. Page 1.
} 
DTF calculations were done with both a void center and a center having polyurethane in it. These calculations gave an indication of how much the polyurethane affected the critical mass in comparison to an assembly with a void center. The calculations showed that the polyurethane would act as a moderator and would decrease the critical mass of the $12.00-\mathrm{cm}$ inner radius assembly by $3.5 \%$. The polyurethane was not as affective a moderator for the smaller assemblies and it decreased the critical mass of these assemblies by a smaller amount.

The DTF calculations are from $3.1-\mathrm{kg}$ to $1.66-\mathrm{kg}(3.8$ to $6.9 \%$ ) lower than the experimental values. This same trend was noted by G. Tuck ${ }^{3}$ in RFP-907 with DTF calculations done on similar shaped assemblies having a different moderator.

'Table VI. gives a complete summary of the calculational and experimental results.

The worth of the petroleum jelly, the mild-steel mounting-bolt, and the aluminum mounting-stands has previously been reported. ${ }^{3}$ The worth of the petroleum jelly as measured on a solid sphere is $0.7 \pm 0.2$ kilograms. The worth of the mounting-bolt is less than $0.4 \%$ of the critical mass of the solid sphere and a smaller percentage for the larger assemblies since the bolt is no longer displacing as large a percent of the uranium in the assembly. The worth of the aluminum mounting-stand is less than $0.2-\mathrm{kg}$ as measured on a solid sphere.

The plus or minus accuracy on the extrapolated critical mass was estimated from the length of the extrapolation and the shape of the curve. The error does not include any allowances for the stand, bolt, or petroleum jelly.

An empirical analysis was done which relates the volume-to-surface ratio of the assemblies to their critical mass. ${ }^{1}$ This analysis is given in Appendix B and it is shown that the critical mass of the spherical uuvumblioo can be doocribed, within experineulal error, in terms of the ir volume-to-surface ratio.

\footnotetext{
${ }^{3}$ Loc. cit. Page 1.
}

${ }^{3}$ Loc. cit. Page 1.
${ }^{1}$ Loc. cit. Page 1.

TADLE VI. Summaly uf Experlmental Results O1l Reflected Polylipethāne îjỏerated Spherical Assemblies.

\begin{tabular}{|c|c|c|c|c|c|c|c|}
\hline $\begin{array}{l}\text { Inside } \\
\text { Hadius } \\
(\mathrm{cm}) \\
\end{array}$ & . & $\begin{array}{c}\text { Experimental } \\
\text { Critical } \\
\text { Mass } \\
\left(\mathrm{kg}^{\prime}\right) \\
\end{array}$ & $\begin{array}{c}\text { Estimated } \\
\text { Arrurery } \\
\left(\mathrm{kg}_{\mathrm{g}}\right) \\
\end{array}$ & $\begin{array}{c}\text { Assembly } \\
\text { Jhencityr } \\
\left(\mathrm{g} / \mathrm{cm}^{3}\right)\end{array}$ & $\begin{array}{c}\text { Fxperimeulal } \\
\text { Outor Radius } \\
\text { (cm) }\end{array}$ & $\begin{array}{c}\text { Enriched } \\
\text { Uranium } \\
\text { Thickniss } \\
\text { (rm) }\end{array}$ & $\begin{array}{c}\text { DTF } \\
\text { Calchulated } \\
\text { Ciilical Mass } \\
\left(k_{g}\right)\end{array}$ \\
\hline 0.000 & & 24.2 & \pm 0.3 & 18.09 & 6.9 & 6.9 & 22.539 \\
\hline 4.017 & & 31.6 & $+1.7-0.9$ & 18.15 & 7.8 & 3.8 & 29.959 \\
\hline 8.010 & $\cdot$ & 52.1 & $+1.2-1.0$ & 18.14 & 10.6 & 2.6 & 50.353 \\
\hline 12.011 & & 81.3 & \pm 3.0 & 18.15 & 14.1 & 2.1 & 78.207 \\
\hline
\end{tabular}

a Calculated from the experimental critical mass, the assembly density, and the assemblies' inner radius.

\section{APPENDIX A.}

\section{SPECIFICATIONS OF TEST MATERIALS}

A. Enriched Uranium Experimental Components.

1. Isotopic content: weight percent: $-93.1{ }^{235} \mathrm{U}$.

2. Density: $18.765 \pm 0.065 \mathrm{~g} / \mathrm{cm}^{3}$.
B. Reflector Oil.

1. Trade Name: Texaco Number 522 .

2. Specificaliuns:

Density $=0.88 \mathrm{~g} / \mathrm{cm}^{3} . \quad C=0.764 \mathrm{~g} / \mathrm{cm}^{3}$. $\mathrm{C} / \mathrm{H}=0.54$ (atomic). $\cdot \mathrm{H}=0.1158 \mathrm{~g} / \mathrm{cm}^{3}$. 
Impurities (Spectro graphic analysis) $\mathrm{Ba}, \mathrm{Ca}$, $\mathrm{Mg}$ and $\mathrm{Si}$ - less than $1 \mathrm{ppm}$. No other metals detected. Trace of $\mathrm{Ca}$ and $\mathrm{Mg}$. Sulphur $-0.2 \%$ by weight.

C. Petroleum Jelly.

1. Trade Name: Petrolatum

2. Specifications:

Density $=0.816 \mathrm{~g} / \mathrm{cm}^{3}$.

$\mathrm{C}=\mathrm{C} .85 \mathrm{~g} / \mathrm{cm}^{3}$.

$\mathrm{H} \equiv 0.148 \mathrm{~g} / \mathrm{cm}^{3}$.
Impurities $(\mu \mathrm{g} / \mathrm{g}): \mathrm{Al} \mathrm{2,} \mathrm{Ca} \mathrm{l}, \mathrm{Cu} 3, \mathrm{Fe} \mathrm{l}$, and all other less than 1 .

D. Low-Density Foam.

1. Trade Name: Plasticraft Polyurethane Duo-

Foam 29.

2. Specifications:

Density $=0.045 \mathrm{~g} / \mathrm{cm}^{3}$.

$\begin{aligned}{ }^{*} \mathrm{C} & =65.3 \% . & \mathrm{O} & =20.6 \% . \\ { }^{*} \mathrm{H} & =7.4 \% . & \mathrm{F} & =5.2 \mu \mathrm{g} / \mathrm{g} . \\ { }^{*} \mathrm{~N} & =6.7 \% . & \mathrm{Cl} & =315.7 \mu \mathrm{g} / \mathrm{g} .\end{aligned}$

* Weight percent.

\section{APPENDIX B.}

\section{EMPIRICAL ANALYSIS OF THE CRITICAL MASS IN TERMS OF THE VOLUME-TO-SURFACE RATIO}

Curve fitting methods have previously been applied by Ernst, Schuske, and King ${ }^{2}$ on similar geometrical shapes but having a different moderator in the central cavity. This technique consists in plotting the critical mass of the assembly versus $1 /(\mathrm{V} / \mathrm{S})-\mathrm{B}$ where $\mathrm{V} / \mathrm{S}=$ volume-to-surface ratio and $B$ has the physical interpretation of being the volume-to-surface ratio of an infinitely large assembly. ${ }^{5}$

The constant $B$ can also be interpreted as one-half the critical thickness of an infinite slab reflected with oil

\footnotetext{
${ }^{2}$ Loc. cit. Page 1.

${ }^{5}$ C. L. Schuske and J. W. Morfitt. "An Empirical Study of Some Critical Mass Data." Y-533. Y-12 Plant, Carbide and Carbon Chemicals Corporation, Oak Hidge, Tennessee. December 6, 1949.
}

TABLE VII. Empirical Analysis of Oil Reflected, Polyurethane Moderated, Enriched Uranium Spherical Assemblies.

\begin{tabular}{|c|c|}
\hline $\begin{array}{l}V / S \\
(\mathrm{~cm})\end{array}$ & $\begin{array}{c}1 /(V / S)-0.65 \\
(1 / \mathrm{cm})\end{array}$ \\
\hline 2.281 & 0.613 \\
\hline 1.7895 & 0.878 \\
\hline 1.2906 & 1.56 \\
\hline 1.0386 . & 2.57 \\
\hline
\end{tabular}

on one side and polyurethane on the other. Figure 12 and Table VII show results of this empirical analysis.

FIGURE 12. Empirical Analysis of Oil Reflected, Polyurethane Filled, Enriched Uranium Spherical Assemblies.

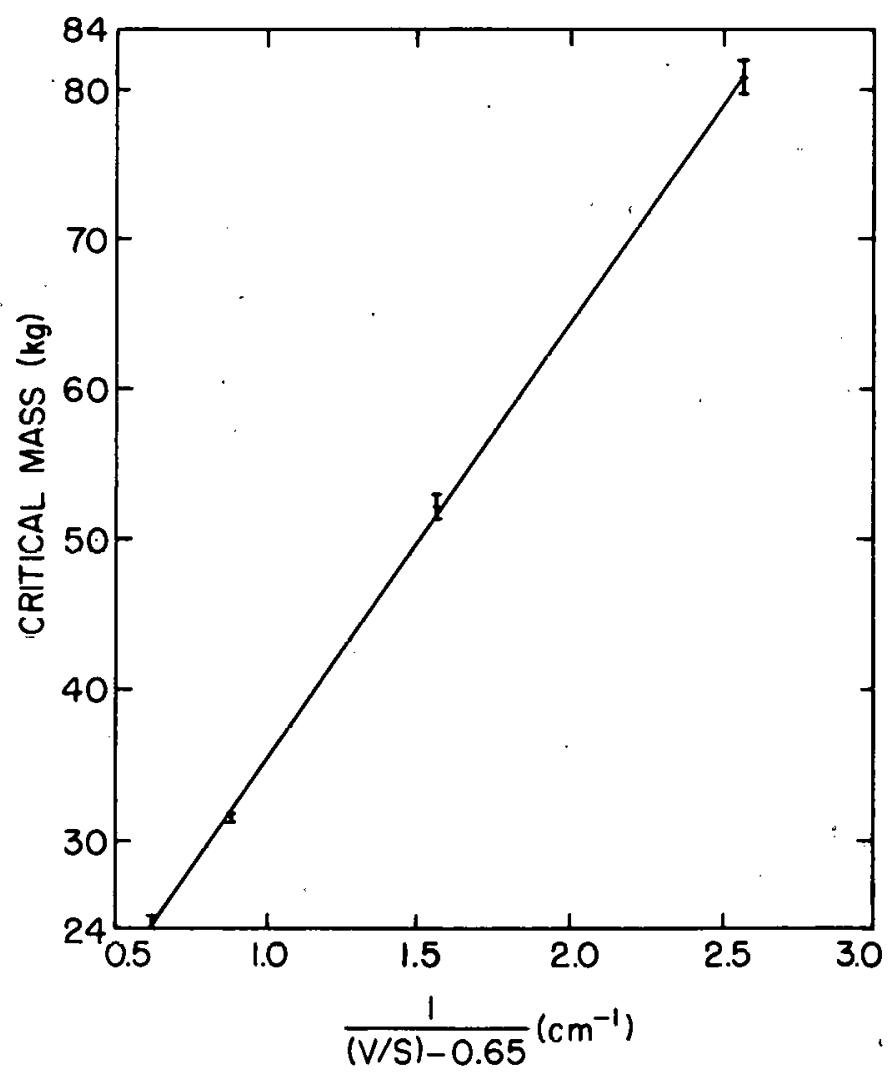

